\title{
Herança colonial confrontada: reflexões sobre África do Sul, Brasil e Estados Unidos
}

\author{
Paulo Sérgio da Costa Neves' (iD) 0000-0001-5489-6429 \\ Laura Moutinho² \\ $0000-0001-6479-2711$ \\ Lilia Katri Moritz Schwarcz ${ }^{2}$ \\ 0000-0003-0498-3246 \\ 'Universidade Federal do ABC, São Bernardo do Campo, SP, Brasil. 09606-045 - \\ secretariacecs@ufabc.edu.br \\ 2Universidade de São Paulo, São Paulo, SP, Brasil. 05508-090-ppgas@usp.br
}

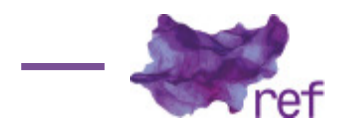

Resumo: Em 09 de março de 2015 centenas de estudantes iniciaram um movimento na prestigiosa University of Cape Town (UCT) para a retirada da estátua de Cecil Rhodes, representante do colonialismo inglês no século XIX, do campus. Nesse mesmo ano, em novembro, estudantes da Princeton University ocuparam a reitoria exigindo que fosse removido de um dos prédios do campus o nome de Woodrow Wilson, defensor da segregação dos negros no sul dos Estados Unidos. Em maio desse ano, a Universidade Federal de Goiás (UFG) foi a primeira universidade do país a implementar reserva de vagas para indígenas, afrodescendentes e deficientes em cursos de pós-graduação. O objetivo deste artigo é compreender e analisar a força desses fenômenos, que são entendidos nessa reflexão como demandas decoloniais com dimensões global e local.

Palavras-chove: Nação; memória; decolonização; universidades; marcadores sociais da diferença.

Colonial Heritage Confronted: Reflections about South Africa, Brazil and the United States Abstract: On March 9, 2015 hundreds of students began a movement at the prestigious University of Cape Town (UCT) for the campus retreat of the statue of Cecil Rhodes, representative of English colonialism in the nineteenth century. That same year, in November, Princeton University students occupied the rectory demanding that the name of Woodrow Wilson, a defender of black segregation in the southern US, was removed from one of the campus buildings. In May of that year, the Federal University of Goiás (UFG) was the first university to implement vacancies reserved for indigenous, afro-descendants and disabled people in postgraduate courses. The objective of this article is to understand and analyze the strength of these phenomena, which are understood in this reflection as decolonial demands with global and local dimensions. Keywords: Nation; Memory; Decolonization; Universities; Social markers of difference.

Em 09 de março de 2015 centenas de estudantes iniciaram um movimento na prestigiosa University of Cape Town (UCT) para a retirada da estátua de Cecil Rhodes do campus. Esta demanda prendia-se ao fato de que Rhodes havia sido, entre o final do século XIX e o início do século XX, o representante mais bem-sucedido do imperialismo inglês no sul da África, tendo-se tornado proprietário de imensas extensões de terra além de minas de ouro e de diamantes na região. Ao morrer, em 1902, Rhodes legou importantes fundos para algumas instituições universitárias sul-africanas, dentre as quais a UCT, o que explica a existência da estátua. Para os estudantes que protestavam contra a presença do monumento em honra desse personagem histórico no campus, contudo, longe de se homenagear a imagem de um benemérito da universidade, isso remetia a um passado colonial de opressão da população não branca (sobretudo, negra e coloured) no país.'

${ }^{1}$ A categoria branca - white ou european - como era utilizada no período do regime de segregação racial conhecido como apartheid, que dominou o país de 1948 a 1994 - não deve ser considerada como uma categoria que experimentou o privilégio e a dominação coloniais de modo homogêneo. No caso em tela, o foco se dirigia 
O movimento, conhecido como \#RHODES MUST FALL, alastrou-se rapidamente para praticamente todas as universidades sul-africanas e, para além da demanda de retirada de uma estátua de um imperialista do século XIX (que foi, de fato, removida do campus da UCT um mês após o início do movimento, em 09 de abril de 2015), incorporou toda uma discussão acerca da presença de uma mentalidade colonial nas universidades e na sociedade sul-africanas. Esse discurso anticolonial teve repercussão inclusive na antiga metrópole colonial da África do Sul, o Reino Unido, uma vez que, desde junho de 2015, um grupo de estudantes da University of Oxford, uma das mais antigas e conceituadas da Inglaterra, demandou também a retirada de uma estátua de Cecil Rhodes do campus desta universidade.

Nesse mesmo ano, em novembro, estudantes da Princeton University, uma das mais conceituadas instituições de ensino superior dos Estados Unidos, ocuparam a reitoria exigindo que, dentre outras medidas, fosse retirado de um dos prédios do campus o nome do antigo aluno, reitor da universidade, e ex-presidente da República, Woodrow Wilson. Os estudantes alegavam que, como Wilson havia defendido a segregação dos negros no sul dos EUA, a universidade deveria se posicionar de forma crítica quanto ao seu papel nas relações raciais no país e mudar o nome do prédio.

Apesar de o conselho universitário ter rejeitado essa demanda, a direção da universidade fez pronunciamentos críticos à atuação política de Woodrow Wilson em relação à questão racial e ao racismo no país e se comprometeu a buscar uma melhor integração dos estudantes negros no seio da universidade.

Aproximadamente no mesmo período, em maio de 2015, a Universidade Federal de Goiás foi a primeira universidade brasileira a implementar reserva de vagas para indígenas, afrodescendentes e portadores de deficiência em todos os cursos de pós-graduação. Antes disso, uma série de Programas de Pós-Graduação isolados já vinha adotando políiticas afirmativas para o ingresso de indígenas e afrodescendentes nos cursos de mestrado e doutorado, respondendo assim a reivindicações de estudantes e militantes dos movimentos negros. Para estes, essa seria uma medida que visaria não apenas à redução das desigualdades de acesso de negros, pardos, indígenas e brancos pobres nesses cursos, mas também atuaria no sentido de ampliar o processo de descolonização do saber nas universidades brasileiras, ao possibilitar que pessoas com visões de mundo diferentes do modo ocidental hegemônico pudessem adentrar os espaços de produção do conhecimento que são as pós-graduações. Questões relativas ao sexismo (patriarcado), a homo e à transfobia perpassam e interpelam transversal ou diretamente essas demandas (ver Zethu MATEBENI, 2017).

O impacto dessas reivindicações tem levado diversas universidades a se posicionarem favoravelmente à implantação de políticas afirmativas em seus cursos de pós-graduação, sobretudo, após o Ministério da Educação ter publicado uma portaria, em maio de 2016, inquirindo todas as universidades federais sobre as suas políticas de inclusão de negros e indígenas nos cursos de mestrado e doutorado.

Essas três situações mostram-nos certas semelhanças. Apesar de todas as cores e características locais, percebemos a existência de um ativismo de estudantes universitários autoclassificados como não brancos, atentos à permanência da estrutura de privilégio e prestígio coloniais, que demandam políticas afirmativas e mudanças simbólicas no modo de representação das populações afrodescendentes. O objetivo dessas demandas seria, para alguns deles, descolonizar as universidades, redimensionando símbolos e o lugar que conhecimentos não ocidentais teriam nas universidades e, para outros, democratizar o acesso de populações não brancas e/ou à margem da estrutura de distribuição de privilégios a lugares de formação de elites.

Nos três casos citados é visível um desejo de modificar a composição do alunado e, também, de questionar o atrelamento simbólico das universidades com a história e o conhecimento produzidos com a marca do "ocidente", o que em muitos discursos se concretizava no termo "descolonização".

O objetivo deste texto é compreender esse fenômeno em suas dimensões global e local. ${ }^{2}$ Para isso, usaremos o expediente clássico da comparação internacional, pondo as realidades brasileira, sul-africana e norte-americana para dialogar entre si. Não pretendemos com isso subsumir uma dessas realidades às outras, acompanhando, portanto, algumas das linhas de força que

especialmente ao imperialismo britânico e à dominação colonial africânder - forma como os descendentes de holandeses são conhecidos. Coloured é a categoria utilizada para mestiço na África do Sul. Um termo racial que em nada se assemelha às categorias que marcam a mestiçagem no Brasil. Black ou african pode designar a vasta e variada população negra (Khosa, Zulu, Venda etc.). Uma categoria que eventualmente é utilizada politicamente para designar todos os que não são brancos.

${ }^{2}$ Essa reflexão foi viabilizada a partir da pesquisa e experiência do autor e das autoras no projeto "A vizinhança nas entrelinhas: alianças e conflitos, trocas (des)iguais e cooperação entre Moçambique e África do Sul" (projeto selecionado na Chamada MCTI/CNPq n 46/2014 - Programa de Cooperação em Ciência, Tecnologia e Inovação com Países da África-PROÁFRICA), financiado pelo CNPq e coordenado por Laura Moutinho. Além de uma ampla rede de colaborações, integraram a pesquisa: Brigitte Bagnol, Esmeralda Mariano, José Ricardo Ayres, Lilia Schwarcz, Paulo Sérgio da Costa Neves, Pedro Lopes e Rita Simone Liberato, tendo sido incorporadas ao longo do processo as pesquisadoras Denise Dias Barros, Carla Braga, Solange Rocha, Gabriela Calazans, Isabel Noronha e Susan Holland-Muter. 
estruturam os estudos de antropólogos brasileiros realizados em países africanos (Laura MOUTINHO; Wilson TRAJANO FILHO; Andrea LOBO, 201 7b), mas, apenas, em um jogo de espelhos típico das pesquisas comparativas, mostrar o que em cada realidade é um fenômeno local e o que pode ser associado a tendências mais gerais.

Partimos da hipótese, cara a muitos pesquisadores das ciências humanas (Arjun APPADURAI, 1996; Ulrich BECK, 2006), de que alguns fenômenos sociais, apesar de terem fisionomias locais evidentes e importantes para as explicações avançadas, precisam ser analisados em suas configurações supranacionais para que possamos apreender sua complexidade. Não estamos longe, nesse sentido, da problemática acerca do cosmopolitismo e do pós-colonialismo que tem sido avançada por diversos autores para entender as dinâmicas sociais em nossas sociedades (Homi BHABHA, 1998).

Em outras palavras, através de uma análise multissituada (George MARCUS, 1995), nos propomos a discutir o modo e a força em cada uma das sociedades estudadas (duas democracias recentes do Sul Global e uma consolidada, um império sem colônia, para usar as palavras de Anne MCCLINTOCK, 2010), bem como o papel simbólico das universidades para pensar o igualitarismo, discutir a desigualdade e forjar políticas que visam à promoção da justiça em relação às minorias que se veem sistematicamente excluídas da estrutura de distribuição de poder e prestígio.

\section{Nação e Memórias em transe}

Um dos pontos em comum nas situações relatadas anteriormente é o esforço dos atores sociais em redimensionar as memórias e narrativas nacionais construídas em torno da herança ocidental, reivindicando pertenças e apontando exclusões e apagamentos. Ao demandar a supressão de homenagens a personagens que no passado estiveram ligados às estruturas de dominação e exclusão das populações negras nos EUA e na África do Sul, ou a presença de povos tradicionais e de negros em espaços de produção do conhecimento no Brasil, está se argumentando pela aceitação de um outro olhar sobre o passado e sobre o modo como as identidades nacionais se consolidaram nesses países.

O uso político da memória social tem sido explorado, sobretudo em relação ao período de constituição dos Estados nacionais que, para autores como Eric HOBSBAWN (1984), foram marcados pela criação de tradições que se queriam discursos nacionais capazes de integrar toda a população em uma mesma identidade.

A propósito, deve-se destacar um interesse específico que as "tradições inventadas" podem ter, de um modo ou de outro, para os estudiosos da história moderna e contemporânea. Elas são altamente aplicáveis no caso de uma inovação histórica comparativamente recente, a "nação", e seus fenômenos associados: o nacionalismo, o Estado nacional, os símbolos nacionais, as interpretações históricas, e daí por diante. Todos estes elementos baseiam-se em exercícios de engenharia social muitas vezes deliberados e sempre inovadores, pelo menos porque a originalidade histórica implica inovação (HOBSBAWN, 1984, p. 23).

Em resumo, a invenção de tradições nacionais foi a lógica que permeou o processo de construção das identidades e dos estados nacionais, consolidando narrativas que soldavam (não sem violência) solidariedades entre grupos heterogêneos.

Esses discursos visavam à criação de comunidades imaginadas (Benedict ANDERSON, 1991) a partir de mitos e símbolos partilhados, de versões nacionalistas do passado que buscavam fixar uma memória capaz de congregar simbolicamente os membros de um grupo ou de um país. Essa fixação nacionalista da memória coletiva (Maurice HALBWACHS, 1990) se fará de diversas maneiras, desde livros e canções até os chamados lugares da memória (Pierre NORA, 1993). Tratase, sem dúvida, do uso da memória como estratégia de construção de identidade nacional e de lógicas de pertencimento a um lugar, mas também meios de transmissão de certos valores e visões de mundo. Um processo que se afirma de modo complexo envolvendo também um emaranhado de instituições, burocracias, leis, práticas e tecnologias de governo (Antonio Carlos de SOUZA LIMA, 2002; Adriana VIANNA, 2014; MOUTINHO, 2004; 2012; 2017a).

Este será o cerne da crítica de Frantz FANON (1968) ao nacionalismo, incluindo aquele de alguns intelectuais engajados na construção das jovens nações africanas após a independência, na medida em que, para ele, o nacionalismo estava prenhe de uma visão colonial, em que os valores ocidentais apareciam como universais e civilizatórios, o que será um ponto central na reivindicação de descolonização das memórias e do saber pelos estudantes das universidades nos três países estudados, como veremos a seguir.

Essa problemática ganha um maior relevo em um momento de globalização cultural e econômica, em que a circulação de pessoas, ideias e recursos ganha uma proporção inusitada. Desse modo, para Nora (1993), isso significou uma mudança importante em relação ao período áureo do nacionalismo e dos Estados-nações: se os monumentos públicos eram lugares de memória 
no passado, com a mundialização e a emergência das identidades multiculturais, estaríamos em uma época das comemorações, em que a multiplicidade de memórias sociais levaria à multiplicidade comemorativa, cada grupo buscando para si a sua comemoração específica. Deste modo, o autor afirma que as memórias estariam lutando contra a história (entendida como história oficial, como sacralizada pelo Estado). Isso levaria a uma transformação dos lugares onde esta se ancora, o patrimônio, uma vez que esses passariam a ser reposicionados simbolicamente a partir das lutas de memória.

Não estamos longe, aqui, das reflexões de Paul RICOEUR (2007) sobre memória, história e esquecimento, mostrando o quanto tais lutas são também para definir qual memória será esquecida ou não, tanto no plano individual quanto social.

Como dirá Fanon (1968) ao tentar demonstrar os efeitos perversos do colonialismo:

Talvez não tenha sido suficientemente demonstrado que o colonialismo não se contenta em impor sua lei ao presente e ao futuro do país dominado. Ao colonialismo não basta encerrar o povo em suas malhas, esvaziar o cérebro colonizado de toda forma e todo conteúdo. Por uma espécie de perversão da lógica, ele se orienta para o passado do povo oprimido, deforma-o, desfigura-o e aniquila-o. Essa tarefa de desvalorização da história do período anterior à colonização adquire hoje sua significação dialética (p. 175).

Nessa perspectiva, o colonialismo é entendido aqui não apenas como práticas políticas de dominação, mas também como formas de subjugação ideológica e cultural as quais incluem, como queria Edward SAID (1990), a construção do exotismo e as percepções que os colonizados têm de si mesmos. Esse constructo, que não é apenas ideacional, funda o Estado estabelecendo um contrato social que é organizado tanto em termos sexuais e de gênero quanto étnicos ou raciais (Veena DAS, 2006; MOUTINHO, 2004; McCLINTOCK, 2010).

É justamente para combater essa lógica colonial que os discursos decoloniais almejam repensar a história e os valores herdados dessa tradição de supervalorização dos modelos europeus em detrimento dos valores dos grupos e povos subalternizados por essa mecânica confrontando as lógicas de gênero, sexualidade e raça dos contratos sociais estabelecidos.

É dentro desse contexto mais amplo de ressignificações do nacional que podemos situar os movimentos em universidades buscando redimensionar as heranças etnocêntricas e históricas das instituições universitárias, espaços tradicionalmente vistos como reprodutores dos valores oriundos do colonialismo e de uma visão unívoca das identidades nacionais, raciais, étnicas, sexuais e de gênero.

\section{O Movimento \#Rhodes Must Fall na África do Sul}

Após a redemocratização do país, em 1994, buscou-se, na África do Sul, romper com a pesada herança do regime do apartheid de diversas maneiras. Em uma tentativa de refundar o país em bases democráticas e multiculturais, uma nova constituição foi elaborada (The Bill of Rights), baseada na igualdade entre todos os cidadãos e no reconhecimento dos direitos culturais das diversas etnias que compõem o país. Para exorcizar os demônios do passado, foi estabelecida também uma Comissão da Verdade e da Reconciliação, a qual buscava, através dos princípios da justiça restaurativa, expiar e perdoar as violências cometidas durante o antigo regime (MOUTINHO, 2012).

Ao mesmo tempo, o desejo de reduzir as desigualdades herdadas do período do apartheid levou o governo sul-africano a implantar ações afirmativas em diversas áreas. Assim, foram elaboradas políticas específicas para a população não branca, especialmente, para os classificados como Africans, Coloureds e Indians, ${ }^{3}$ a fim de ajudá-los a se inserir no mercado de trabalho, no âmbito educacional e no mundo empresarial desde os primeiros anos dos governos democráticos. A questão da classificação racial/étnica nesse cenário é complexa - como mostram as análises de Laura Moutinho (2004; 2012; 2015; 2017a); Moutinho et al. (2010) e Pedro LOPES; Moutinho (2012) - não podendo ser entendida no pós-apartheid como uma simples inversão de uma lógica de discriminação negativa para positiva nem tampouco operada de modo unívoco para as diferentes categorias étnico-raciais. Foi o grupo classificado como African (eventualmente referido como black, non-european e/ou bantu - ver também nota 1 deste texto) que sofreu particularmente com a exclusão de acessos a educação, emprego, sistema de saúde durante o regime de exceção.

Dentre estas políticas destacam-se a Employment Equity (EE) Act No 55 em 1998 e a Black Economic Empowerment (BEE) Act No 53 de 2003. Trata-se de medidas legislativas voltadas para garantir a inserção dos grupos discriminados durante o apartheid na vida econômica (através de subsídios para empresários negros ou empresas que tivessem um número importante de negros em sua diretoria, da exigência de ter um corpo de funcionários que expresse a diversidade da população sul-africana etc.). Elas tinham um evidente viés de buscar sanar as desigualdades do

${ }^{3}$ Africans, Coloureds e Indians são categorias usadas pelo censo sul-africano para designar as populações preta, mestiça e de descendentes dos trabalhadores trazidos da Índia no início do século passado. 
passado através da integração da população no mercado, criando as condições para o desenvolvimento de uma classe média negra.

Contudo, os resultados dessas políticas têm recebido muitas críticas de especialistas, uma vez que o nível de desigualdades do país sofreu pouca alteração. Em sua análise a respeito dos resultados das principais medidas de reparação voltadas para a população negra, a BEE, Jenny CARGILL (2010), que foi ela própria uma participante da elaboração das leis e códigos que deram origem a essas políticas (code of good practice), critica o fato de o ANC (ou, em português, CNA, Congresso Nacional Africano - partido de Nelson Mandela, que liderou o processo de democratização) ter centrado sua política de combate às disparidades entre brancos e negros na dimensão do empreendedorismo, foco das ações ligadas à BEE. Com isso, a ênfase na propriedade que aparece nas políticas da BEE deixa de lado outros aspectos importantes para a integração da população negra, tais como a repartição das terras ou uma política habitacional de sucesso.

Uma consequência inesperada da BEE teria sido a "dominance of broad-based companies among produtive BEE investitors". Ou seja, a adoção da BEE por grandes empresas (único meio para obter financiamento público) através da incorporação de acionistas negros resultou no fato de que elas se tornaram as maiores beneficiadas pela ajuda pública ligada à $B E E$, o que leva essa autora a se questionar sobre a eficácia destas medidas com relação à redução da pobreza no país. Dito de outro modo, para alguns críticos da BEE, as medidas adotadas, além de não promoverem um real empoderamento dos negros mais pobres, eram economicamente ineficientes e promoviam a corrupção e o patrimonialismo pela elite da ANC.

Contudo, as ações afirmativas no âmbito educacional são bem mais tímidas que as ações no âmbito do empreendedorismo. Apesar disso, algumas universidades têm introduzido políticas preferenciais de seleção de alunos, o que tem gerado um intenso debate sobre o assunto. De acordo com Max PRICE (2012), Vice-Chanceler da Universidade do Cabo, uma das mais reputadas do país: ${ }^{4}$

Em resumo, hoje há poucas pessoas que discordam que ações afirmativas sejam necessárias e desejáveis na admissão de estudantes na educação superior na África do Sul. Em geral, a controvérsia não diz respeito à desvantagem ser parte do processo seletivo. Ao contrário, diz respeito ao uso da raça como marcador de desvantagem e reparação.

Existem dois argumentos fundamentais contra o uso da raça. O primeiro é que a categorização racial mina nosso comprometimento nacional com o não-racialismo [nonracialism]. Forçanos, especialmente os mais jovens nascidos na época das primeiras eleições democráticas, a ver o mundo, a eles próprios e aos outros em termos de categorias raciais.

O segundo argumento contra a raça como base para ação afirmativa é que isso pode incluir alunos negros que não são, certamente, desfavorecidos, que podem ter vindo de lares mais abastados que a maior parte dos alunos brancos e podem ter tido o benefício de 12 anos de educação em escolas privadas.

Isso injustamente desfavorece um aluno branco aplicado e talvez menos abastado em favor de um aluno negro que teve notas baixas, unicamente porque o último é negro.

O que esse debate nos mostra é que, apesar da questão do ensino superior não ter sido um objeto de legislação como foram as ações afirmativas no âmbito da economia, algumas universidades do país estão implantando de forma autônoma políticas preferenciais para a população black (e em menor medida coloured e indian). A ausência de políticas públicas voluntaristas nesse setor parece sugerir que a urgência para muitos homens públicos se situa no âmbito econômico e, sobretudo, no âmbito do empreendedorismo. As críticas de alguns atores políticos importantes às prioridades dos governos da ANC vão insistir no fato de que a educação, assim como outros setores, foi deixada em segundo plano em relação à $B E E$.

Crítica que vai além, obviamente, do espectro das ações afirmativas adotadas, pois diz respeito às escolhas macroeconômicas dos governos do ANC. Certamente por trás dessas apreciações negativas há tanto a desconfiança de que a hierarquia da ANC está se beneficiando com a centralidade da BEE nas políticas públicas, quanto também a percepção de que a prioridade ao empreendedorismo significa uma capitulação às políticas e princípios liberais.

De todo modo, do ponto de vista educacional, a opção feita foi de incitar as universidades a adotar políticas para aumentar a diversidade de seus corpos discente e docente sem, contudo, impor cotas fixas para isso, ficando cada universidade responsável pelo estabelecimento dos critérios que seriam adotados para atingir tal objetivo. Todavia, dadas as deficiências das escolas públicas do ensino fundamental e médio ${ }^{5}$ em que os alunos negros são maioria, e dado o fato de que o sistema universitário do país está assentado no pagamento de anuidades e que as bolsas previstas para alunos carentes são limitadas, a proporção de alunos não brancos, ainda que em processo de crescimento, não tem o mesmo peso da população como um todo.

${ }^{4}$ Todas as traduções deste texto foram realizadas por Thais Tiriba (PPGAS/USP) e revisadas por Laura Moutinho (PPGAS/ USP).

${ }^{5} \mathrm{O}$ que se chama de ensino público na África do Sul é bastante diferente da compreensão e funcionamento dessa ideia no Brasil. 
Assim, por exemplo, se examinarmos o percentual de alunos brancos na University of Cape Town (UCT), considerada a melhor universidade do país, notaremos que eles eram 45\% em 2013. Percentual menor que os $60 \%$ de 1994 , mas bem maior que a proporção de brancos na sociedade sul-africana (cerca de $8 \%$ em 2015).

Como dito, essas políticas tiveram várias consequências no âmbito das relações entre os grupos raciais/étnicos no país. Por um lado, promoveram a emergência de uma classe média negra, tendo, porém, poucas repercussões na diminuição das desigualdades sociais. Por outro lado, nos espaços universitários, consolidaram a presença de estudantes não brancos, os quais vão reivindicar cada vez mais que as administrações universitárias levem em conta suas demandas e necessidades.

Nesse sentido, um certo sentimento de decepção com as políticas implementadas depois da democratização pode ser percebido em várias esferas. Na esfera midiática, isso era perceptível nas críticas frequentes desde o início dos anos 2000 à corrupção do governo e ao uso partidário de certas políticas afirmativas, a exemplo da BEE.

Muitos dos estudantes da UCT e da Universidade de Stellenbosch com quem conversamos partilhavam do mesmo sentimento de Carol SPREEN e Salim VALY (2006):

Os acordos negociados na África do Sul, a Comissão da Verdade e Reconciliação, as cláusulas da Declaração dos Direitos na Constituição e o estabelecimento de organizações estatutárias como a Comissão sul-africana de Direitos Humanos e a Comissão para a Igualdade de Gênero, com todo o importante trabalho que realizaram, ainda disfarçam as diferenças sociais fundamentais entre as pessoas na África do Sul. A linguagem dos direitos mascara a privação e obscurece essa realidade apresentando os direitos como se fossem comuns a todos, apesar de serem inatingíveis para a maioria. Prosseguir como se os direitos existissem para todos inibe a habilidade das pessoas em reconhecer as circunstâncias quando elas são, de fato, ilusórias (p. 353).

Para muitos jovens sul-africanos, a herança de Mandela e Desmond Tutu, que priorizaram a reconciliação e o reconhecimento das identidades, precisa ser reavaliada. E, neste ponto, há uma incômoda proximidade entre essa crítica e aquela elaborada pela extrema direita religiosa (MOUTINHO, 2012; 2015). Essa compreensão foi vocalizada pelo políitico da oposição Julius Malema durante o debate sobre a divisão das terras produtivas no país ao longo de 2018: "The time for reconciliation is over; now is the time for justice".

De todo modo, é nesse contexto de debate político intenso sobre a herança da democratização e do apartheid que surge o movimento \#Rhodes Must Fall (RDF), inicialmente na UCT e, logo em seguida, em praticamente todas as universidades sul-africanas.

O movimento nasce quando o estudante da UCT, Chumani Maxwele, lança um balde contendo fezes humanas na estátua de Cecil Rhodes localizada no campus, como forma de protesto contra a presença de uma estátua de um imperialista do século XIX em uma universidade pública. O uso de fezes era uma forma de protestar contra a falta de banheiros e de condições de higiene nas favelas (townships) da cidade (MATEBENI, 2017).

A administração da UCT, que a princípio se recusara a negociar a retirada da estátua, à medida que o número de alunos se avolumava, viu-se compelida não só a removê-la como também a discutir uma série de reivindicações dos alunos black, indian e coloured. Dentre os principais pontos dessa pauta de reivindicações destacam-se: luta contra o racismo institucional; descolonização da educação através de mudanças nos currículos com vistas a dar maior peso aos saberes africanos e criar mecanismos para facilitar o acesso de jovens negros, de forma a ampliar o número de estudantes negros em relação aos brancos e direta ou transversalmente as questões relativas a interseccionalidade de gênero, raça, sexualidade e classe (além da raça e do racismo) - foram fundamentais.

Como um rastilho de pólvora, o movimento vai se alastrar para outras universidades tanto da África do Sul como de outros países - o caso de Oxford, na Grã-Bretanha, é exemplar, onde alunos sul-africanos beneficiários de bolsas de estudos do Instituto Cecil Rhodes irão replicar o movimento poucas semanas após seu início em Cape Town.

Diversos autores sublinharam já que "The RMF movement seeks to decolonize education by employing tactics of disruption inspired by decolonial, black consciousness and intersectional theories" (Kayun AHMED, 2017, p. 8). Com isso, buscou-se mostrar tanto as influências intelectuais do movimento, quanto os objetivos que os militantes desse movimento davam a si mesmos.

Desse modo, no documento lançado pelo coletivo em Cape Town no início do movimento, vai-se afirmar o desejo de lutar contra o ambiente institucional:

Somos um coletivo independente de alunos, trabalhadores e funcionários que se uniu para acabar com o racismo e o patriarcado institucionalizados na UCT. Esse movimento foi desencadeado pelo protesto radical de Chumani Maxwele contra a estátua de Cecil John Rhodes na segunda-feira, 9 de março de 2015. Isso trouxe à tona a raiva existente e justificada de alunos negros no espaço opressivo cultivado e mantido pela UCT, apesar de sua retórica de 'transformação' (Achille MBEMBE et al., 2015). 
Do mesmo modo, há um alerta contra a ideia de que se trata apenas da derrubada de uma estátua:

Queremos deixar claro que esse movimento não diz respeito somente à remoção de uma estátua. A estátua tem um grande poder simbólico; ela glorifica um assassino em massa que explorou o trabalho dos negros e roubou terra de indígenas. Sua presença apaga a história negra e é um ato de violência contra alunos, trabalhadores e funcionários negros - por "negro" nos referimos a todas as pessoas de cor [people of colour]. A estátua foi, dessa maneira, 0 ponto de partida natural desse movimento. Sua remoção não vai marcar o fim, mas o começo de um processo, que se inicia muito tardiamente, de descolonizar essa universidade. Em nossa opinião, as experiências que buscam ser abordadas por esse movimento não são exclusivas de uma instituição de elite como a UCT, mas, ao contrário, refletem as dinâmicas mais amplas de uma sociedade racista e patriarcal que permaneceu inalterada desde o fim do apartheid formal (MBEMBE et al., 2015).

Para isso, o movimento chamava atenção para o sofrimento dos blacks (entendidos como todos não brancos) não só ao longo da colonização e da vigência do apartheid, mas também na contemporaneidade no interior da UCT.

Na raiz dessa luta está a desumanização de pessoas negras na UCT. Essa desumanização é uma violência exercida apenas contra pessoas negras por um sistema que privilegia a branquitude [whiteness]. Nossa definição de negro inclui todas as pessoas de cor [people of colour] racialmente oprimidas. Nós adotamos essa identidade política não para desconsiderar as enormes diferenças que existem entre nós, mas precisamente para interrogá-las, identificar as raízes nas táticas de dividir e conquistar da supremacia branca e agir em unidade para promover nossa libertação coletiva. É, dessa forma, crucial que esse movimento flua das vozes negras e das dores negras que foram continuamente ignoradas e silenciadas (MBEMBE et al., 2015).

O movimento se queria também como uma forma de lutar contra uma certa interpretação histórica do período colonial, trazendo para a ordem do dia a presença simbólica do colonialismo na vida universitária. Ele se quer também como um meio de trazer à baila diversas assimetrias sociais alimentadas pela visão colonial, o que vai se materializar no conceito de interseccionalidade:

Queremos afirmar que, enquanto esse movimento emergiu como resposta ao racismo na UCT, nós reconhecemos que as experiências de opressão nesse campus são interseccionais e nós temos como objetivo adotar uma abordagem daqui em diante que seja consciente disso. Uma abordagem interseccional à nossa negritude [blackness] leva em consideração que não somos definidos apenas por nossa negritude [b/ackness], mas que alguns de nós são também definidos por nosso gênero, nossa sexualidade, nossa corponormatividade [able-bodiedness], nossa saúde mental e nossa classe entre outras coisas. Nós todos temos certas opressões e certos privilégios e isso deve informar nossas formas de organização para que nós não silenciemos grupos entre nós, e para que ninguém tenha que escolher entre suas lutas. Nosso movimento se empenha em tornar isso realidade em nossa luta pela descolonização (MBEMBE et al., 2015).

Para implementar essas demandas, o coletivo busca se distanciar das concepções universalistas defendidas na Constituição do país, vistas como concepções racistas por associar qualquer reivindicação com base na raça de racista:

Em consonância com nossas posições, rejeitamos o policiamento das respostas de alunos negros às suas experiências violentas. Queremos acrescentar que sentimos que a concepção de racismo da Constituição é fundamentalmente racista, pois pressupõe que o racismo seja uma experiência universal, normalizando assim o sofrimento daqueles que de fato experienciam o racismo. [...] A concepção de racismo da Constituição tem sido sistematicamente usada para deter impulsos irreprimíveis de sul-africanos negros ao desafiarem o racismo e a violência. Um exemplo disso foi a decisão da Comissão de Direitos Humanos contra o Fórum de Jornalistas Negros, quando jornalistas brancos foram banidos da organização em fevereiro de 2008 e isso foi declarado inconstitucional e racista. Um exame da história política sul-africana releva a necessidade de pessoas negras se organizarem sem pessoas brancas na luta contra o racismo (MBEMBE et al., 2015).

Se analisarmos as principais reivindicações apresentadas pelo grupo à administração da universidade, elas iam no sentido de criticar os monumentos e nomes de vias públicas, em geral dedicadas a celebrar a memória de personagens brancos ligados aos valores coloniais, de demandar mudanças nos currículos, julgados como euro-centrados e sem referências à África, mudanças nas políticas da memória da instituição com relação ao sofrimento dos grupos subalternos, ampliação do número de funcionários, professores e alunos oriundos desses grupos etc.

- Remover todas as estátuas e placas no campus que celebram supremacistas brancos. Renomear prédios e ruas de nomes que comemorem apenas pessoas brancas para nomes de 
figuras históricas negras ou nomes que contribuam para essa universidade levar a sério sua posição africana. - Substituir obras de arte que exotizem a experiência africana (de artistas brancos, predominantemente masculinos) que são apresentadas sem contexto, por obras produzidas por jovens artistas negros. - Reconhecer que a história daqueles que construíram nossa universidade - escravos e trabalhadores negros - foi apagada pela cultura institucional. • Prestar mais atenção aos locais históricos de violência, como as sepulturas de escravos sob os prédios onde aprendemos. - Implementar um currículo que criticamente centralize a África e os subalternos. Com isso nos referimos a tratar os discursos africanos como ponto de partida abordando não apenas o conteúdo, mas as linguagens e as metodologias da educação e da aprendizagem - e examinar tradições ocidentais na medida em que sejam relevantes para nossa própria experiência. - Oferecer apoio financeiro e de pesquisa para acadêmicos e funcionários negros. - Alterar radicalmente a representação de professores negros nas faculdades. - Rever as limitações no acesso de acadêmicos negros a cargos sênior. Isso inclui interrogar a noção de "excelência acadêmica" que é usada para limitar o avanço de acadêmicos e estudantes negros dentro da universidade. - Aumentar a representação de acadêmicos negros nos órgãos responsáveis pela tomada de decisão que são atualmente predominantemente brancos e masculinos e que perpetuam o racismo institucional. - Reavaliar os critérios a partir dos quais as áreas de pesquisa são decididas - de áreas que são lucrativas e centralizam a branquitude [whiteness], para áreas que sejam relevantes para as vidas de pessoas negras localmente e no continente. - Introduzir um currículo e uma área de pesquisa relacionada à justiça social e às experiências de pessoas negras. - Adotar uma política de admissão que use raça como critério para desvantagem, priorizando candidatos negros (MBEMBE et al., 2015).

Como se vê, a gama de reivindicações é extensa e toca em alguns aspectos que vão além da questão da estátua de um homem público e empresário a serviço do Império Britânico do século XIX. Essas reivindicações significam mudanças radicais no modo como a universidade está organizada, de como a memória histórica é preservada e do questionamento das relações de gênero e interseccionais que informam os contratos sociais (desiguais) estabelecidos, o que gerou um grande número de debate tanto na sociedade sul-africana como em outros países, dadas as repercussões desse movimento em outras universidades.

Assim, por exemplo, em um texto críicco ao movimento, o pesquisador sênior da Universidade de Oxford, Anthony LEMON (2016), vai questionar o desejo de mudar e ressignificar a memória histórica dos estudantes militantes de RMF na África do Sul e na Inglaterra. Para ele, o risco em se reescrever a história seria perder a sua identidade.

A questão mais ampla levantada pela campanha é como nós vivemos com nossa história. A controvérsia de Rhodes não é de forma alguma excepcional. Ela é parte de uma demanda mais ampla para 'descolonizar a produção de conhecimento', ligada a conceitos de 'espaço seguro' [safe space] que buscam banir determinados palestrantes de campi universitários e libertá-los de tudo o que possa ofender. Estudantes de Princeton queriam remover o nome de Woodrow Wilson do edifício do campus por conta de suas alegadas conotações racistas e estudantes da College of Willian and Mary querem remover a estátua de Thomas Jefferson (um proprietário de escravos que também se opôs ao domínio colonial e aceitou a igualdade de todos os homens quando assinou a Declaração de Independência em 1776). Estudantes da Universidade de Oregon até debateram retirar uma citação do discurso 'Eu tenho um sonho', de Martin Luther King, com a justificativa de que ela era insuficientemente inclusiva para as sensibilidades atuais. Há infinitas possibilidades - e Gladstone, cujo primeiro discurso no parlamento incluía uma defesa dos interesses da plantation de sua família? Mas Stephen Hawking nos lembra, nas palestras Reith desse ano, que 'é o passado que nos diz quem somos. Sem isso, perdemos nossa identidade' (HAWKING, 2016, apud LEMON, 2016). A História, como disse o chanceler de Oxford, Lord Patten, 'não é uma página em branco sobre a qual podemos escrever nossa versão do que deveria ter sido de acordo com nossas visões e preconceitos contemporâneos' (AUSTIN, 2016, apud LEMON, 2016). Uma cultura saudável não deixa de lembrar daqueles com quem veio a discordar. Ao contrário, com a ajuda de historiadores, ela incessantemente debate e revê sua avaliação deles (LEMON, 2016, p. 219).

Nessa mesma direção, John Vickers, um dirigente da Universidade de Oxford, em resposta às demandas do grupo \#Rhodesmustfall-Oxford, vai afirmar que: "The Library exists for students and researchers. Its name and statues reflect facts of history which, like the history of slavery itself, cannot be changed".

O que se percebe nesses textos de dirigentes universitários é uma oposição completa às demandas de mudança e ressignificação da história desses movimentos nas universidades. De fato, o que o movimento pretendia era ir na direção oposta à ideia de manutenção de uma memória unívoca com o argumento acerca da importância de preservar a história. Para eles, o objetivo era justamente criar uma memória e uma universidade descolonizadas, onde os valores e as tradições subalternas, sobretudo africanas, tivessem direito a um lugar ao sol. Que esse movimento tenha tido repercussões internacionais mostra o quanto essas reivindicações não estão restritas ao contexto sul-africano. 
A evolução do movimento RMF dá uma ideia dos dilemas que cercam essas mobilizações na atualidade. Após a retirada da estátua de Rhodes do campus da UCT em abril de 2015 e da intensa mobilização que se segue em outras universidades sul-africanas, manifestações contra o aumento das anuidades das universidades vão agitar o mundo universitário do país a partir de outubro do mesmo ano e se seguirão até o final de 2016. Essas manifestações, conhecidas como \#FEES MUST FALL (FMF), ganharão contornos mais violentos que o RMF, tanto da parte do Estado, que ocupa militarmente os principais campi universitários, como também dos estudantes, os quais em algumas universidades incendeiam ou depredam prédios.

Embora o foco desses embates fosse a reivindicação para a redução ou extinção das taxas universitárias, consideradas muito elevadas e que dificultavam a entrada e permanência de estudantes negros nas universidades, muitas das reivindicações do RMF foram incorporadas, sobretudo as que dizem respeito às mudanças no currículo.

É difícil avaliarmos o quanto esses movimentos influenciaram as políticas universitárias sulafricanas, mas certamente o anúncio pelo ex-presidente Jacob Zuma de que as taxas universitárias seriam extintas para os estudantes pobres em dezembro de 2017 , o que foi confirmado pelo novo presidente Cyril Ramaphosa em março de 2018, mostra uma preocupação do governo em atender a uma reivindicação que vai além dos estudantes e tem uma certa simpatia da opinião pública.

No interior das universidades, pudemos conversar com alguns responsáveis pela administração que relataram esforços para ampliar o recrutamento de professores negros e sulafricanos e de criar melhores condições para o acolhimento de alunos negros (com relação ao quesito da língua e/ou as condições de alojamento etc.). Além disso, muitos coletivos para a descolonização das universidades continuam ativos e realizam atividades regularmente.

Em algumas dessas atividades nota-se uma vertente que atua no sentido de separar brancos e negros. Algo que se enquadra em um processo em voga de racialização (ou, como ouvimos, da reiticização) da política da sociedade sul-africana o processo de democratização buscara eliminar pela introdução de uma constituição liberal e pelo respeito das tradições culturais étnicas. Ou seja, o multiculturalismo, que parecia ser um remédio contra as discriminações e ódios do passado, vem sendo contestado em diversos espaços sociais, inclusive nas universidades por jovens envolvidos em lutas anticoloniais.

Um dos indícios de que isso está ocorrendo são alguns desdobramentos do movimento RMF, quando eventos "Blacks only" passam a ocorrer na universidade. Assim, por exemplo, o jornal "News 24" noticia, em 22/06/2018, a repercussão de um jantar organizado por alunos ativistas onde não eram aceitas pessoas brancas: "Os organizadores de um jantar, planejado para a University of Cape Town's (UCT) Decolonial Winter School (DWS), a qual convidou "POC only" (pessoas de cor apenas), não se desculpam por sua postura, apesar da reação das mídias sociais", ${ }^{6}$ anunciava o artigo. Contudo, para os organizadores do evento, esse seria um espaço de trocas de experiência entre não brancos sem a pressão do olhar do outro. Vejamos as suas palavras:

\begin{abstract}
'Um espaço onde pessoas negras podem descomprimir'
"O coletivo decidiu que são as pessoas negras que são sobrecarregadas com o processo de descolonização", disse a organizadora da DWS e ativista estudantil Alex Hotz.

"Nesses espaços que envolvem pessoas brancas, muitas vezes achamos que pessoas negras são forçadas a se autocensurar para proteger a fragilidade branca. Era para ser um espaço onde as pessoas negras pudessem descomprimir."

Hotz disse que o programa também focava em "desafiar noções básicas liberais de racismo". "Recebemos muitas reações de pessoas brancas nas mídias sociais que argumentavam que isso equivalia à segregação", ela disse.

"Estamos desafiando noções básicas liberais de racismo, que se relacionam com o poder estrutural e sistêmico. É irônico porque pessoas brancas se mantiveram em silêncio durante o apartheid e estão em silêncio sobre os benefícios que continuam a colher devido ao privilégio branco" (Christina PIT, 22/06/2018).
\end{abstract}

De igual modo, alguns relatos de estudantes fizeram menção a tensões entre africans, coloureds e asians durante os movimentos \#Rodhes must fall e \#Fees must fall, onde a discussão girava em torno de qual grupo havia sido mais discriminado e, portanto, merecia maior reparação. Da mesma forma, algumas militantes fizeram referências à repressão que as mulheres LGBT sofreram no interior dos movimentos, sobretudo no período FMF, por conta do machismo e da cultura viril prevalecente nos ambientes estudantis. Em artigo Seção Temática, Susan HOLLAND-MUTER (2019) articula de modo sensível questões relativas à homossexualidade, a vida queer e, especialmente, sobre as lésbicas negras de Cape Town e a forma como circulam e fazem a própria cidade. Um cenário que precisa ser compreendido no interior de uma gramática moral que, em parte, e apenas em parte, diferencia Brasil da África do Sul (Thais TIRIBA, 2019, nessa Seção Temática) e para seguir na perspectiva comparada aberta por TIRIBA (2019), vale observar a controvérsia em

${ }^{6}$ No original: "The organisers of a supper, planned for the University of Cape Town's (UCT) Decolonial Winter School (DWS), which invited 'POC only' (people of colour), are unapologetic about their stance, despite social media backlash". 
relação à homossexualidade no Brasil em Peter FRY e Sérgio CARRARA (2016), que também possui paralelos com a África do Sul.

Em resumo, estes teriam sido alguns dos pomos de discórdia entre militantes que, ao lado da criminalização dos movimentos pelo Estado, explicariam o refluxo das mobilizações a partir de 2016.

O que parece evidente nesse cenário é o fato de que esses movimentos buscam redimensionar e retraduzir a experiência colonial e a memória do apartheid de forma a propor uma visão diferenciada do processo de redemocratização do país. Nesse sentido, não seria exagero afirmamos que o que está em jogo nessas reivindicações é o modo como alguns jovens sul-africanos pensam e vivem a identidade sul-africana e como eles se veem nela.

\section{Universidades de elite e o ajuste de contas com o passado: experiência dos EUA}

Em novembro de 2015 o vistoso Nassau Hall - edifício onde se localiza o escritório do presidente da Universidade de Princeton, Christopher Eisgruber - foi invadido por alunos, em boa parte negros. Durante 32 horas eles permaneceram sentados no saguão do prédio neoclássico, numa linguagem de protesto bem conhecida na tradição civil norte-americana: o sit-in ou sit-down. Promoveram ainda uma verdadeira gincana de eventos que demandava, dentre outros pontos, a remoção do nome de Woodrow Wilson da famosa escola e residência de alunos, homônima.

O local, a demanda, a instituição e a escola, cujo nome está agora em litígio, não poderiam ser mais simbólicos. Princeton faz parte da Yvy League - 8 universidades privadas (que recebem subsídios dos cofres públicos, de todo modo) localizadas na região Nordeste dos Estados Unidos, de reconhecido prestígio, e que inclui estrelas como Yale, Harvard e Brown. Já a Woodrow Wilson School of Public and International Affairs produziu e produz quadros famosos de Princeton, sendo uma espécie de cartão de visitas da instituição.

A batalha girava em torno de um nome, mas não apenas um nome. Thomas Woodrow Wilson (1856-1924) foi presidente dos Estados Unidos por dois turnos subsequentes, permanecendo no cargo de 1912 a 1921. Era membro do Partido Democrata, foi Nobel da Paz em 1919 e reitor da própria Universidade de Princeton. W. Wilson é, porém, figura polêmica e que serve para muitas causas e propósitos. De um lado, destacou-se na luta pela Sociedade das Nações, um dos modelos que inspirou a criação futura da $\mathrm{ONU}$, e atuou em favor das populações vitimizadas pela Primeira Guerra Mundial. Por outro lado, ficou igualmente conhecido por suas convicções racistas. Segundo o historiador Eric YELLIN (2013), o presidente acreditava que negros não mereciam a plena cidadania; era um admirador da Ku Klux Klan; e, como interventor militar na América Latina, tomou parte na decisão que levou à invasão de países como Nicarágua, México, Panamá e Haiti.

Já a própria Universidade de Princeton, nos seus primeiros anos, era conhecida como o limite último para estudantes advindos das famílias senhorias do sul dos EUA, que muitas vezes, dizem as memórias, faziam-se acompanhar de seus escravos domésticos.

Por essas e por outras é que o nome do ex-reitor e presidente era prato cheio, o que acabou transbordando para os protestos que tomaram 0 , em geral pacato, campus da universidade de Princeton: essa era apenas a ponta de um iceberg bicudo. Os estudantes em protesto demandavam também um espaço cultural dedicado a graduandos e pós-graduandos negros; um curso de orientação sobre temas raciais para toda a comunidade de Princeton, bem como programas sobre "história de povos marginalizados" na grade fixa da Universidade.

Segundo uma das participantes do movimento, o objetivo era mudar o modo como a instituição contava sua história e demonstrar maior respeito para com os não brancos:

Essa universidade está encarregada de educar seus alunos e, sem esses padrões, sem garantir que todos os estudantes sejam tratados com a mesma quantidade de respeito e humanidade, e sem mostrar um comprometimento robusto para elevar as contribuições, histórias e experiências de pessoas negras e outras pessoas de cor [people of color], Princeton (e muitas outras universidades) estão falhando em conseguir educar os alunos de forma completa (Ellen BRAIT, 23/11/2015).

Para ela, ainda, esse era um meio para convencer a maioria branca das universidades de elite nos Estados Unidos que o racismo era bem real e cotidiano nessas instituições.

Pessoalmente, eu acho que as conversas que inflamaram nas universidades eram inevitáveis. Como estudante de uma instituição predominantemente branca, sentir como se tivesse que convencer as pessoas da discriminação e lutar para ser vista como um ser humano é cansativo e frustrante. A partir de um certo ponto, os estudantes vão reagir a esse sentimento, especialmente quando são afirmados pela história dos arquivos, e ainda mais quando sentem que as instituições não reagem (ou se recusam a reagir) com rapidez suficiente a uma mudança justa (BRAIT, 23/1 1/ 2015).

Embora o principal objetivo do movimento não tenha sido alcançado, pois a universidade se negou a mudar o nome dos prédios, em abril de 2016 sua administração vai reconhecer que: 
Princeton deve reconhecer abertamente e candidamente que Wilson, como outras figuras históricas, deixa para trás um complexo legado de repercussões tanto positivas quanto negativas, e que o uso de seu nome não implica no endossamento de visões e ações que estão em conflito com valores e aspirações de nosso tempo. Nós dissemos isso nesse relatório, e a Universidade deve dizer isso nos espaços que carregam seu nome (Barbara GOLDBERG, 04/04/2016).

Além disso, a universidade vai se comprometer a introduzir medidas para ampliar a diversidade do campus bem como de sua iconografia.

O furacão que vem anunciando tempestade sobre Princeton não é, porém, fenômeno isolado. Universidades do Missouri à Yale têm passado por apertos semelhantes, assim como a Brown University, que vem dando lição nessa área: cursos, seminários e exposições foram realizados, bem como uma pesquisa sobre a história da sua instituição, o que inclui vasculhar o constrangedor passado escravocrata da região e de membros fundadores da sua universidade. Aliás, a presidente da Brown, Ruth J. Simmons - a primeira afro-americana e a segunda mulher a ocupar uma posição como essa numa Yvy League -, conhecida por sua militância pelas causas civis, esteve em Princeton para uma conferência e - como nada nesse mundo é mera coincidência - "sentou" com os alunos para conversar. Também em Princeton a situação vai mudando: foi realizado um primeiro curso sobre a escravidão em New Jersey, e uma organização de estudantes, chamada "Black League of Justice", tem liderado esse tipo de movimento. O fato é que o tema tornou-se viral com partidários da causa usando hashtags como "student blackout".

Ocupações de estudantes motivadas por demandas sociais conformam um tema que conhecemos bem aqui no Brasil. A espinhosa e até então silenciosa questão racial entrou finalmente na pauta, e veio para ficar. Já a novidade em Princeton é o perfil ordeiro desse evento - nada foi quebrado; alunos receberam alimentação da universidade; tinham à sua disposição pilhas de garrafas de água na entrada da porta do Nassau Hall, e bucólicas tendas de acampamento foram montadas nos jardins do campus. Para os padrões de Princeton, a agitação era total e absoluta.

Mas há sempre muita mudança na permanência. História é jogo complexo, e sabemos bem como personagens do passado podem ser revisitados a partir de novos ângulos. Sem fazer exercício fácil do anacronismo, e cobrar atitudes do presente a personalidades do passado, o fato é que há muita poeira por trás do nome de W. Wilson e pólvora pronta para estourar no edifício de mármore da escola de Public Affairs, que ostenta orgulhoso na ocasião, bem à frente de sua fachada, as esculturas do zodíaco do artista chinês Ai Weiwei, conhecido ativista político em seu país. A novidade é também a resposta corajosa da própria Universidade de Princeton, que enviou documento pedindo por "compromisso e imaginação". Entre outras ponderações, afirmou ainda que "consideraria" a remoção do nome de W. Wilson da escola em questão.

Claro está que o debate só começou e muitos outros vão se anunciando. Um grupo de alunos saiu a público e afirmou sentir-se muito bem representado pelo presidente em disputa: eles são identificados e se autoidentificam como "conservadores" ou "Tories de Princeton". Estudantes latinos, cuja associação data de 2007, animaram o segmento com o "Latinxs", enquanto movimentos de alunos muçulmanos e chineses estão aproveitando a onda para ganhar nova visibilidade. O importante é que diferentes segmentos vêm se organizando para reivindicar suas diferenças e o direito a serem parte integral numa comunidade muito exclusiva.

Lutas por demandas civis - essa linguagem que implica pensar no direito à diferença na igualdade - têm tomado a nossa agenda e promovido mudanças transformando a sensibilidade social. Pedir pela pluralidade, contar histórias diferentes e igualmente verdadeiras, reclamar novas formas de justiça, exigir igualdade e inclusão social, reconhecer sofrimentos inscritos em detalhes dispersos no cotidiano, mas também em grandes realidades, é desafio para todos nós. Conforme escreveu o presidente de Princeton, esses são "tempos turbulentos e demandantes". Mudar um nome não é com certeza uma solução. Mas é um bom sinaleiro; uma ótima provocação.

Movimentos sociais como esses, e tantos outros que nos são familiares, têm tido o mérito de incluir novas vozes e dissonâncias. Também nos ajudam a "imaginar" que boas agendas são aquelas que suscitam não a criação de dicotomias intransigentes, mas o diálogo frente a causas que nos permitem sentar em, com e para.

\section{Reivindicações Decoloniais e Democratização das universidades brasileiras}

No Brasil, o debate acerca da descolonização do conhecimento nas universidades e na sociedade brasileira ganha força a partir dos anos 2000 , quando as primeiras iniciativas de ações afirmativas no âmbito do ensino superior e da educação básica foram instituídas. Nesse sentido, a introdução das primeiras experiências de reservas de vagas para negros e pobres nas universidades estaduais do Rio de Janeiro, em 2001, a aprovação da lei 10.639, em 2003, sobre a obrigatoriedade de inclusão de conteúdos sobre a história e a cultura afro-brasileira no ensino 
público fundamental e médio, a elaboração do Plano Nacional de Implantação das Diretrizes Curriculares Nacionais para a Educação das Relações Étnicas (BRASIL, 2004), a criação da SEPPIR (Secretaria Especial de Promoção da Igualdade Racial), em 2001, e da SECAD (Secretaria de Educação Continuada, Alfabetização e Diversidade do MEC), em 2004, entre outras iniciativas, eram vistas como formas de lutar contra a exclusão social e simbólica das populações afrobrasileiras e indígenas, bem como um meio de tornar as narrativas identitárias oficiais mais abertas à diversidade e menos eurocêntricas.

Os debates, inicialmente monopolizados pelo tema da cotas universitárias, rapidamente vão versar sobre outras dimensões da luta antirracista, influenciando as ações estatais e os discursos dos movimentos sociais negros. Assim, no próprio texto da lei 10.639, de 2003, o objetivo de revalorizar a história dos negros no Brasil é explícita:

Art. 26-A. Nos estabelecimentos de ensino fundamental e médio, oficiais e particulares, torna-se obrigatório o ensino sobre História e Cultura Afro-Brasileira.

$\S 10$ O conteúdo programático a que se refere o caput deste artigo incluirá o estudo da História da África e dos Africanos, a luta dos negros no Brasil, a cultura negra brasileira e o negro na formação da sociedade nacional, resgatando a contribuição do povo negro nas áreas social, econômica e política pertinentes à História do Brasil (BRASIL, 2003).

Esta lei seria modificada posteriormente, mantendo praticamente a mesma redação, mas com a inclusão da cultura e história dos povos ameríndios como conteúdo obrigatório nos ensinos fundamental e médio:

$\S 1^{\circ} \mathrm{O}$ conteúdo programático a que se refere este artigo incluirá diversos aspectos da história e da cultura que caracterizam a formação da população brasileira, a partir desses dois grupos étnicos, tais como o estudo da história da África e dos africanos, a luta dos negros e dos povos indígenas no Brasil, a cultura negra e indígena brasileira e o negro e o índio na formação da sociedade nacional, resgatando as suas contribuições nas áreas social, econômica e políitica, pertinentes à história do Brasil (BRASIL, 2008).

Apesar das dificuldades na implementação dessas leis, percebe-se claramente que o objetivo explícito dos que as redigiram era o de modificar a percepção histórica acerca das comunidades negras e indígenas, bem como de repensar a história oficial do país, vista como excessivamente eurocêntrica e voltada para as contribuições do ocidente na formação nacional.

Isso é o reflexo do fato de que a ação estatal a partir dos anos 1990 seguia no sentido de ressignificar a identidade nacional e de pôr em prática políticas de valorização simbólica das populações negra e indígena do país. Essas mudanças se deram em parte por conta da aproximação de militantes antirracistas dos governos de centro-esquerda e, também, pela influência do contexto internacional de valorização das minorias étnicas, sobretudo, após a conferência de Durban (Terceira Conferência Mundial contra o Racismo, a Discriminação Racial, a Xenofobia e Formas Correlatas de Intolerância) promovida pela ONU contra o racismo e o preconceito em 2001.

Contudo, o debate sobre a "descolonização do saber" mobilizaria de forma mais intensa os estudantes universitários em torno das ações afirmativas voltadas para favorecer uma maior presença de negros e indígenas nas universidades, sobretudo no que diz respeito às pósgraduações. Desse modo, a partir de 2012, ano em que as cotas se tornaram obrigatórias nas graduações das universidades federais, diversos coletivos negros foram criados nas universidades públicas reivindicando cotas para negros e indígenas nas pós-graduações.

Para diversos atores sociais, essas cotas seriam meios de lutar contra o saber colonial e, assim, elas seriam uma forma privilegiada de descolonização das universidades brasileiras, seja pela introdução de temáticas ligadas às populações tradicionais, induzidas pela maior presença de estudantes destes grupos nos programas de pós-graduações, seja pela possibilidade de diversificação do corpo docente que uma maior quantidade de mestres e doutores de grupos não brancos possibilitaria. A ideia de que uma maior diversidade do corpo discente e, também, docente, seria um elemento que alavancaria a legitimidade de saberes afro-brasileiros tradicionais no campo acadêmico passa então a ocupar um espaço importante nas justificativas para a introdução dessas ações afirmativas.

Nessa perspectiva, para a "União de Estudantes de São Paulo", ao defender, em 20 de novembro de 2018, a adoção de políticas afirmativas na Universidade de São Paulo (USP), as cotas significariam uma mudança profunda na produção do conhecimento produzido nessa universidade, uma vez que:

A chegada dos cotistas é fundamental para a democratização do ensino e, também, para uma verdadeira transformação no conhecimento que é produzido. Como uma universidade de pesquisa, a USP produz ciência e tecnologia de ponta, mas a pesquisa realizada pelos corpos docente e discente permanece afastada das necessidades da população brasileira, e para a promoção do desenvolvimento econômico, social e cultural do país é imprescindível que a universidade esteja conectada às diversidades e realidades existentes em nossa sociedade (BORGES, 2018). 
Assim, depois das cotas nas graduações, diversas experiências se desenvolveram para a introdução de ações afirmativas nas pós-graduações. Inicialmente voltadas para indígenas e depois para afro-brasileiros, outros grupos serão beneficiados com o tempo, a exemplo de portadores de deficiência, demandadores de asilo e a população LGBTI.

Fruto de demandas de estudantes e de professores de diversas instituições, as primeiras experiências de vagas reservadas nas pós-graduações se dão em universidades em que grupos organizados passam a pressionar as administrações universitárias para introduzir políticas afirmativas voltadas para indígenas e afro-brasileiros. Assim, a primeira experiência deu-se na Universidade Federal do Amazonas, com a introdução de cotas para indígenas no Programa de Pós-Graduação em Antropologia Social, em 2011. Em 2012, foi a vez do Programa de PósGraduação em Antropologia reservar vagas para indígenas, negros e pessoas deficientes - esta última é uma categoria importante no Norte e no Sul Global (Pedro LOPES, 2019, nesta Seção Temática). Ainda em 2012, o Programa de Pós-Graduação em Antropologia do Museu Nacional, Universidade Federal do Rio de Janeiro, introduz vagas reservadas para negros e indígenas. Em 2015, a Universidade Federal de Goiás foi a primeira a introduzir reserva de vagas para indígenas, afro-brasileiros e deficientes (20\% no total) em todos os programas de pós-graduação da universidade, o que logo em seguida leva diversas outras universidades a seguirem caminho semelhante (João FERES Jr. et al., 2018).

Todos esses fatos mostram que, no Brasil, a demanda por um redimensionamento da memória e da história nacionais passa também por uma discussão sobre a maior presença da população não branca nas universidades e por uma discussão sobre o modo como o conhecimento vem sendo produzido nesse âmbito. Nesse sentido, no caso brasileiro, as reivindicações decoloniais nas universidades, da mesma forma que na África do Sul e nos EUA, passavam tanto por uma discussão sobre revisitar a história nacional quanto pela demanda de políticas com o objetivo de tornar as universidades mais abertas às populações carentes e outros grupos mal representados nesse campo educacional.

Estava em jogo também uma forma de reivindicar uma memória nacional crítica ao colonialismo e aberta ao reconhecimento das contribuições não ocidentais para sua constituição. Os coletivos negros criados nos últimos anos nas universidades brasileiras, com a reivindicação de dar voz aos jovens negros recém-ingressos, dão conta dessa tendência.

Essa crítica à herança histórica colonial pode também ser sentida em outras esferas da sociedade brasileira; um exemplo disso foi a pichação de vermelho do monumento aos bandeirantes e do monumento a Borba Gato em São Paulo, em setembro de 2016. Nesse caso, como nos mostra Lilia SCHWARCZ (2017), o objetivo dos pichadores era o de protestar contra uma visão edulcorada da ação dos chamados bandeirantes para a história nacional, uma vez que eles foram responsáveis pela escravização de indígenas e pela repressão de movimentos rebeldes variados.

No momento em que escrevemos este texto, uma série de mudanças na política brasileira parece indicar que aos novos governantes não agradam muito nem a ideia de se repensar a história nacional (dando maior protagonismo às populações indígenas e negras), nem as políticas afirmativas visando tornar as instituições de ensino superior mais plurais. Como isso vai se materializar em termos de políticas públicas e de reações dos grupos organizados na sociedade civil ainda é uma incógnita, mas esse novo processo certamente incitará novas e desafiantes pesquisas nos meses e anos vindouros.

\section{Conclusões}

Vemos, assim, que nos três países mencionados anteriormente se nota um movimento para redefinir as histórias e as identidades nacionais oficiais. Nos três casos, grupos subalternos e intelectuais críticos buscam redefinir seus lugares econômicos e/ou simbólicos na estrutura social nacional de cada país, seja através de debates sobre monumentos ou sobre as relações de poder no interior das universidades (o modo de acesso, a composição social, étnica e de gênero dos corpos discentes e docentes, os saberes considerados como legítimos, as tradições e monumentos que são cultuados etc.).

O que há em comum nesses movimentos é a oposição a uma tradição etnocêntrica e europeia, que via na transmissão dos valores ocidentais um projeto civilizatório e modernizante: é justamente contra esse projeto que grupos de jovens oriundos de setores simbolicamente desfavorecidos (negros nos Estados Unidos e na África do Sul, negros e indígenas no Brasil) vêm se organizando e forçando mudanças. Nesse esforço há, certamente, um desejo de transformações dos projetos nacionais hegemônicos e dos lugares simbólicos dos grupos subalternos.

Estamos, pois, diante de novas modalidades de lutas sociais, onde o espaço simbólico ocupa um lugar primordial nas reivindicações; lutas por reconhecimento que, na tradição hegeliana representada por Taylor ou Honneth, significam redimensionar os lugares simbólicos dos grupos nas comunidades imaginadas (ANDERSON, 1991) dos Estados nacionais contemporâneos (Paulo NEVES; Luiz Gustavo da Cunha de SOUZA, 2019). 
De um certo modo, há aqui um reflexo dos processos de democratização recentes das sociedades brasileira e sul-africana e também de ascensão social de indivíduos dos grupos minoritários a partir das ações afirmativas nos três países. Em outras palavras, a ascensão de grupos subalternizados leva-os a contestar o lugar simbólico que eles ocupam no imaginário nacional, reivindicando ao mesmo tempo maior integração social em termos econômicos e de prestígio social.

Apesar das especificidades nacionais, esses eventos não são isolados, pois demonstram uma tendência mundial das lutas sociais de grupos minoritários. Como diversos autores têm insistido (APPADURAI, 1996; BECK, 2006), as lutas sociais ganharam novas dimensões simbólicas nas últimas décadas do século XX e nas primeiras do século XXI. Demandas identitárias por reconhecimento (Charles TAYLOR, 1992; Axel HONNETH, 2008) que implicam um redimensionamento dos lugares simbólicos dos grupos nas identidades nacionais, mas também demandas por integração social e participação paritária (Nancy FRASER, 2009). Isso teria levado a uma internacionalização dos critérios de justiça (FRASER, 2009) e, em contextos democráticos (como os dos países em tela), ao aparecimento de movimentos sociais reivindicando ações reparatórias de injustiças sofridas no passado e reavaliações das memórias sociais que serviam de base às identidades nacionais, tal qual elas haviam sido consolidadas pelos Estados nacionais ao longo do século XX (Paulo NEVES, 2019).

A crítica ao colonialismo, tanto em termos de reinterpretação da história, quanto em termos de refutação de uma "mentalidade colonial" (FANNON, 1968), ganha sentido e corpo quando grupos oriundos de segmentos minoritários passam a ocupar certos espaços de poder e prestígio, como são as universidades. Nesse sentido, essa crítica é um efeito indireto das ações afirmativas que facilitaram o acesso de minorias às universidades, mas que não implicaram mudanças substanciais nos modos operandi dessas instituições.

Desse modo, as reivindicações dos estudantes sul-africanos dos movimentos \#RHODES MUST FALL e do \#FEES MUST FALL põem em evidência os limites da democratização sul-africana, a qual, apesar de ter posto fim ao apartheid legal, não foi capaz de transformar a lógica estruturante dessas relações, em que as disparidades entre brancos e negros continuam elevadas, sobretudo, nas universidades onde os saberes ditos tradicionais são vistos como resquícios do passado, confinados a departamentos sem muita expressão no interior da instituição.

Do mesmo modo, nos Estados Unidos, as reivindicações de estudantes negros em grandes universidades expressam o mal-estar sentido em espaços majoritariamente brancos e com uma memória oficial presa a símbolos e personagens que sustentaram a escravidão e o sistema Jim Crown, que negava os direitos civis aos negros no passado.

No Brasil, as demandas por uma maior presença de negros nos espaços universitários ligados à pesquisa e à produção do conhecimento se deram paulatinamente à reivindicação por uma revalorização simbólica dos não brancos na história oficial, além de uma "decolonização do saber". Independente do que foi "sucesso" ou "fracasso" nessas reivindicações, o que esses três casos nos mostram é a complexidade das controvérsias em torno da memória social. Elas dizem respeito, especialmente, ao modo como esta está estruturada (HALBWACHS, 1990). A pujança dos movimentos retratados nessa reflexão, e de outros congêneres, indica que cada vez mais as disputas em torno das memórias têm um papel decisivo em sociedades que ainda não conseguiram conciliar a história oficial com as contingências democráticas de nossa época: é o modelo de sociedade que se deseja que está em disputa, informado por distintos princípios de justiça (Paulo NEVES, 2005). A emergência de tendências contrárias à manutenção do status quo histórico, racial, social e de gênero nesses três países mostra, assim, que essas questões estão longe de gerarem um consenso, especialmente nesses tempos turbulentos.

\section{Referências}

AHMED, Kayum. “\#RhodesMustFall: Decolonization, Praxis and Disruption”. Journal of Comparative \& International Higher Education, n. 9, p. 8-13, 2017.

ANDERSON, Benedict. Comunidades Imaginadas: Reflexões sobre a origem e a difusão do Nacionalismo. São Paulo: Companhia das Letras, 1991.

APPADURAI, Arjun. Modernity at Large. Cultural Dimensions of Globalization. Minneapolis: University of Minnesota Press, 1996.

BECK, Ulrich. The Cosmopolitan Vision. Cambridge: Cambridge Polity Press, 2006.

BHABHA, Homi. O Local da Cultura. Belo Horizonte: EDUFMG, 1998.

BORGES, Bianca. “OPINIÃO: Cotas na USP: o que mudou e quais os próximos desafios?”. UEE - União Estadual dos Estudantes de São Paulo, 2018. Disponível em https://ueesp.org.br/opiniao-cotas-nausp-o-que-mudou-e-quais-os-proximos-desafios/. Acesso em 05/01/2019. 
BRAIT, Ellen. "Princeton students demand removal of Woodrow Wilson's name from buildings". The Guardian, 23/11/2015. Disponível em https://www.theguardian.com/education/2015/nov/23/ princeton-woodrow-wilson-racism-students-remove-name.

BRASIL. Lei $n^{\circ}$ 10.639, de 9 de janeiro de 2003. Altera a Lei n 9.394, de 20 de dezembro de 1996, que estabelece as diretrizes e bases da educação nacional, para incluir no currículo oficial da Rede de Ensino a obrigatoriedade da temática "História e Cultura Afro-Brasileira", e dá outras providências. Brasília, 2003. Disponível em http://www.planalto.gov.br/ccivil_03/leis/2003/110.639.htm.

BRASIL. Lei $n^{\circ}$ 11.645, de 10 de março de 2008. Altera a Lei n 9.394, de 20 de dezembro de 1996, modificada pela Lei $n^{\circ} 10.639$, de 9 de janeiro de 2003, que estabelece as diretrizes e bases da educação nacional, para incluir no currículo oficial da rede de ensino a obrigatoriedade da temática "História e Cultura Afro-Brasileira e Indígena". Brasília, 2008. Disponível em http:// www.planalto.gov.br/ccivil_03/_Ato2007-2010/2008/Lei/L1 1645.htm.

BRASIL. Plano Nacional de Implantação das Diretrizes Curriculares Nacionais para Educação das Relações Étnico-raciais para o Ensino de História e Cultura Afrobrasileira e Africana. Brasília: MEC, 2004. Disponível em http://etnicoracial.mec.gov.br/images/pdf/diretrizes_curric_educ_etnico raciais.pdf.

CARGILL, Jenny. Trick or Treat: rethinking black economic empowerment. Johannesburg: Jacana Media, 2010.

DAS, Veena. Life and Words: Violence and the descent into the ordinary. Berkeley: University of California Press, 2006.

FANON, Frantz. Os Condenados da Terra. Rio de Janeiro: Civilização Brasileira, 1968.

FERES JÚNIOR, João; CAMPOS, Luiz Augusto; DAFLON, Verônica Tostle; VENTURINI, Ana. Ação afirmativa: conceito, história e debates. 1. ed. Rio de Janeiro: EDUERJ, 2018.

FRASER, Nancy. Scales of Justice. Reimagining Political Space in a Globalizing World. New York: Columbia University Press, 2009.

FRY, Peter; CARRARA, Sérgio. "'Se oriente, rapaz!': Onde ficam os antropólogos em relação a pastores, geneticistas e tantos 'outros' na controvérsia sobre as causas da homossexualidade?". Revista de Antropologia, v. 59, n. 1, p. 258-280, 2016. Disponível em https://doi.org/10.1 1606/21 79-0892.ra.2016. 116920.

GOLDBERG, Barbara. "Despite race views, Princeton to keep President Wilson's name”, Reuters, 04/ 04/2016. Disponível em https://www.reuters.com/article/us-usa-race-princeton-idUSKCNOX1 1 J5.

HALBWACHS, Maurice. A Memória Coletiva. São Paulo: Editora Vértice, 1990.

HOBSBAWN, Eric. "Introdução”. In: HOBSBAWN, Eric; RANGER, Terence (Orgs.). A Invenção das Tradições. Rio de Janeiro: Paz e Terra, 1984. p. 9-23.

HOLLAND-MUTER, Susan. "Making place, making home: lesbian queer world-making in Cape Town". Revista Estudos Feministas, v. 27, n. 3, 2019.

HONNETH, Axel. Disrespect: the Normative Foundations of Critical Theory. Malden: Polity Press, 2008.

LEMON, Anthony. "'Rhodes Must Fall': The Dangers of Re-writing History”. The Round Table, v. 105, n. 2, p. 217-219, 2016.

LOPES, Pedro. "Deficiência como categoria do Sul Global: primeiras aproximações com a África do Sul”. Revista Estudos Feministas, v. 27, n. 3, 2019.

LOPES, Pedro; MOUTINHO, Laura. "Uma Nação de Onze Línguas? Diversidade social e linguística nas novas configurações de poder na África do Sul”. Tomo, UFS, v. 20, p. 27-57, 2012.

MARCUS, George. "Ethnography in/of the World System: The Emergence of Multi-Sited Ethnography". Annual Review of Anthropology, n. 24, p. 95-117, 1995.

MATEBENI, Zethu. "Perspectivas do Sul sobre relações de gênero e sexualidades: uma intervenção queer". Revista de Antropologia, São Paulo, v. 60, n. 3, p. 26-44, dez. 2017.

MBEMBE, Achille et al. (Eds.). UCT Rhodes Must Fall Mission Statement. The Johannesburg Salon, v. 9, 2015. Disponível em http://www.jwtc.org.za/resources/docs/salon-volume-9/FINAL_FINAL_Vol9_Book.pdf. 
McCLINTOCK, Anne. Couro Imperial: Raça, Gênero e sexualidade no embate colonial. Campinas: EDUnicamp, 2010.

MOUTINHO, Laura "The other side? Das implicações morais de certos horizontes imaginativos na África do Sul". Anuário Antropológico, Brasília, UnB, v. 40, n. 2, p. 77-97, 2015.

MOUTINHO, Laura. "Sobre danos, dores e reparações: The Moral Regeneration Movement controvérsias morais e tensões religiosas na ordem democrática sul-africana". In: TRAJANO FILHO, Wilson (Org.). Travessias antropológicas: estudos em contextos africanos. Brasília: ABA, 2012. p. 10-36.

MOUTINHO, Laura. Des braves gens qui s'aiment de détester ensemble. São Paulo, Tese de Livre Docência, Universidade de São Paulo, 2017a.

MOUTINHO, Laura. Razão, "Cor" e Desejo: uma análise comparativa sobre relacionamentos afetivosexuais "inter-raciais" no Brasil e na África do Sul. São Paulo: EDUNESP, 2004.

MOUTINHO, Laura; LOPES, Pedro; ZAMBONI, Marcio; RIBAS, Mario; SALO, Elaine. "Retóricas Ambivalentes: ressentimentos e negociações em contextos de sociabilidade juvenil na Cidade do Cabo (África do Sul)". Cadernos Pagu, n. 35, p. 139-176, 2010.

MOUTINHO, Laura; TRAJANO FILHO, Wilson; LOBO, Andréa. "Dossiê Olhares Cruzados para a África: Trânsitos e mediações - Algumas reflexões". Revista de Antropologia, São Paulo, v. 60, n. 3, p. 7-25, dec. $2017 \mathrm{~b}$.

NEVES, Paulo Sérgio da Costa. "Luta anti-racista: entre reconhecimento e redistribuição". Revista Brasileira de Ciências Sociais, São Paulo, v. 20, n. 59, p. 81-96, 2005.

NEVES, Paulo Sérgio da Costa. "Reconhecimento ou Redistribuição: O que o debate entre Honneth e Fraser diz das lutas sociais e vice-versa". Política \& Sociedade, v. 17, p. 234-257, 2019.

NEVES, Paulo Sérgio da Costa; DE SOUZA, Luiz Gustavo da Cunha. "Redistribuição ou reconhecimento, 15 anos depois". Política \& Sociedade, v. 17, p. 7-20, 2019.

NORA, Pierre. "Entre Memória e História: a problemática dos lugares". Projeto História, São Paulo, PUC-SP, n. 10, p. 12, 1993.

PITT, Christina. "UCT dinner for people of colour only, organisers remain unapologetic". News24, 22/ 06/2018. Disponível em https://www.news24.com/SouthAfrica/News/uct-dinner-for-people-of-colouronly-organisers-remain-unapologetic-20180622.

PRICE, Max. "In defence of race-based policy". Mail \& Guardian, 26/01/2012. Disponível em https:/ /mg.co.za/article/2012-01-06-in-defence-of-racebased-policy.

RICOEUR, Paul. A memória, a história, o esquecimento. Campinas: EDUnicamp, 2007.

SAID, Edward W. Orientalismo: o Oriente como Invenção do Ocidente. São Paulo: Cia. das Letras, 1990.

SCHWARCZ, Lilia. "Ser ou Não Ser; Estátua ou Monumento". Nexo Jornal, 28/08/2017. Disponível em https://www.nexojornal.com.br/colunistas/2017/Ser-ou-n\%C3\%A3o-ser-est\%C3\%A 1 tua-oumonumento. Acesso em 02/02/2019.

SOUZA LIMA, Antonio Carlos de (Org.). Gestar e Gerir: Estudos para uma antropologia da administração pública no Brasil. Rio de Janeiro: Relume Dumará, 2002.

SPREEN, Carol A.; VALLY, Salim. "Education Rights, Education Policies and Inequalities in South Africa". International Journal of Educational Development, n. 26, p. 352-362, 2006.

TAYLOR, Charles. Multiculturalism and "The Politics of Recognition". Princeton: Princeton University Press, 1992.

TIRIBA, Thais. "Sugar relationships: sexo, afeto e consumo na África do Sul e no Brasil". Revista Estudos Feministas, v. 27, n. 3, 2019.

VIANNA, Adriana. "Violência, Estado e Gênero: considerações sobre corpus e corpus entrecruzados". In: SOUZA LIMA, Antonio Carlos de; GARCIA-ACOSTA, Virginia (Orgs.). Margens da violência. Subsídios ao estudo do problema da violência nos contextos mexicanos e brasileiros. Brasília: ABA, 2014. p. 209-237. 
YELLIN, Eric. Racism in the Nation's Service: Government Workers and the Color Line in Woodrow Wilson's America. Chapel Hill: University of North Carolina Press, 2013.

Paulo Sérgio da Costa Neves (paulo.neves@ufabc.edu.br) é doutor em Sociologia e Ciências Sociais pela Université Lumière Lyon 2, bolsista produtividade CNPq e Professor Titular na Universidade Federal do ABC, onde é docente permanente no Programa de Pós-Graduação em Ciências Humanas e Sociais. É também docente permanente do Programa de Pós-Graduação em Sociologia da Universidade Federal de Sergipe.

Laura Moutinho (Imoutinho@usp.br) é Professora Associada (Livre-Docente) do Departamento de Antropologia e do Programa de Pós-Graduação em Antropologia (PPGAS), ambos da USP, e doutora em Antropologia Cultural pela UFRJ. Realizou Pós-Doutorado na Universidade de Princeton, é bolsista produtividade nível $1 \mathrm{D}$ do CNPq, editora da Revista de Antropologia e coordenadora da Comissão Projeto Editorial da Associação Brasileira de Antropologia (ABA).

Lilia Katri Moritz Schwarcz (lili.schwarcz@gmail.com) possui Graduação em História pela USP (1980), Mestrado em Antropologia Social pela Unicamp (1986), Doutorado em Antropologia Social pela USP (1993), Livre-Docência em Antropologia Social pela USP (1998), Titular em Antropologia Social, USP (2005). Atualmente é Professora Titular do Departamento de Antropologia da Universidade de São Paulo (2005), global scholar e Professora Visitante em Princeton (desde 2011 ), editora da Companhia das Letras e bolsista produtividade CNPq.

\section{COMO CITAR ESSE ARTIGO DE ACORDO COM AS NORMAS DA REVISTA}

NEVES, Paulo Sérgio da Costa; MOUTINHO, Laura; SCHWARCZ, Lilia Katri Moritz. "Herança colonial confrontada: reflexões sobre África do Sul, Brasil e Estados Unidos". Revista Estudos Feministas, Florianópolis, v. 27, n. 3, e66960, 2019.

\section{CONTRIBUIÇÃO DE AUTORIA}

Paulo Sérgio da Costa Neves: concepção, coleta e análise dos dados, discussão dos resultados, elaboração do manuscrito e do texto final.

Laura Moutinho: concepção, coleta e análise dos dados, discussão dos resultados, elaboração do manuscrito e do texto final.

Lilia Katri Moritz Schwarcz: concepção, coleta e análise dos dados, discussão dos resultados, elaboração do manuscrito e do texto final.

\section{FINANCIAMENTO}

As pesquisas que deram origem ao texto foram apoiadas por diferentes órgãos de financiamento, a saber: o CNPq foi o principal órgão financiador através do Edital PROÁFRICA e das bolsas produtividade em pesquisa dos três autores do artigo; CAPES (através de bolsa de estudos para doutorandos que participaram do projeto PROÁFRICA/CNPq); FAPESP: Processo 16/09840-0 (através de bolsas de estudos para pós-graduandos que participaram do projeto PROÁFRICA, bem como pelo financiamento do Simpósio "Olhares cruzados para a África: trânsitos e mediações", realizado na USP e na 30a RBA/UFPB, em 2016). A pesquisa contou ainda com o apoio do Programa de PósGraduação em Antropologia da USP.

\section{CONSENTIMENTO DE USO DE IMAGEM}

Não se aplica.

APROVAÇÃO DE COMITÊ DE ÉTICA EM PESQUISA

Não se aplica. 


\section{CONFLITO DE INTERESSES}

Não se aplica.

\section{LICENÇA DE USO}

Este artigo está licenciado sob a Licença Creative Commons CC-BY International. Com essa licença você pode compartilhar, adaptar, criar para qualquer fim, desde que atribua a autoria da obra.

\section{HISTÓRICO}

Recebido em 07/08/2019

Aprovado em 15/08/2019

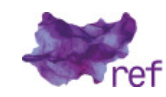

